\title{
Why the Philosopher Kings will believe the Noble
}

\section{Lie}

\author{
Catherine Rowett, \\ University of East Anglia, Norwich UK.
}

At the end of Republic Book 3, when he has just finished describing the education that would produce fine young citizens suited to be Guardians of his ideal state, Socrates famously proposes that all the citizens should be taught a myth or story. They are to identify the earth as their mother, and to believe that, during their gestation within the womb of the earth, different kinds of metals accumulated in their souls, and that these metals are definitive of their future career and place in society.'

We call this story "the Noble Lie". "Noble" translates $\gamma \varepsilon v v \alpha i ̂ 0 v$, meaning "well-born"perhaps because it is about nobility of birth, since all the citizens are nobly born, of the same mother, according to this story, but we shall also find reasons for seeing it is as noble in another sense. "Lie" is translating $\psi \varepsilon \hat{v} \delta o \varsigma$, meaning 'false'. Perhaps "lie" is an over-translation, since, as many have noted, not all falsehoods are lies. We could substitute "fiction" or "pretence" in place of "lie". But regardless of which terms we use, the fact remains that Socrates suggests using falsehood and asks how we might get the citizens to believe a myth which, in some sense at least, is acknowledged to be untrue.

Two puzzles arise from the claim that the story is false. First, if it is obviously untrue, and everyone knows that, how can anyone come to believe it? And second, why should Socrates want his citizens to believe a falsehood, and run the state on that basis, instead of teaching them the truth? The provision of a founding lie, and the requirement that the people be deceived about their own birth, has generated hostility among a wide spectrum of readers. Many readers have jumped to the conclusion that Plato's aim was to conceal the natural equality of the people, so that they could be allotted roles of unequal worth in the community. This makes the story a rather ignoble lie, designed to oppress rather than liberate the people of the ideal state.

\footnotetext{
I $414 b-c$.
} 
My task in this paper is to show that Plato meant exactly the opposite. I shall argue that the Noble Lie is designed to ensure that the city and its citizens are lucidly aware of something that is important and true, and that it is designed to deliver greater fairness and equality of opportunity, to prevent prejudice or privilege due to noble birth or wealth or any other unfair advantages, and to facilitate social mobility.

By juxtaposing the myth of the metals (Noble Lie) with another myth (the "Cave") from later in the same work, I hope to make the point of the Noble Lie more evident. We shall also find that the puzzles about whether it is false, whether it is compatible with justice, and why the rulers would believe it, fall away. By taking a tour through the underground caverns of the Republic we shall emerge at the end with our eyes opened to the truth.

\section{Birth and rebirth}

The Noble Lie comes in two parts. The first is about autochthony (4/4d-e): it claims that people are gestated under the earth, and that the earth is their mother. The second is the "myth of the metals" (4I5a-c): it claims that god infuses a metal deposit into each soul during the gestation under the earth, different metals for different people.

The first point to note about the autochthony part is that it is evidently not about what we call birth. The citizens are not required to believe that they were earth-born as infants, but rather that they were born into adult citizenhood, at the end of their school education. This school-leaving event, presumably at the ephebic age of something like 18 or 20 (537bl-c3), was a kind of "birth from the earth". ${ }^{2}$ The gestation period, preceding this "citizen birth" is the period during which the child is reared by the state education system, which Socrates has just finished describing.

Here is what Socrates says:

${ }^{2} 4$ I4d (TI). Several previous scholars have observed (in a footnote) that this event must be or may be an event at the ephebic age (e.g. G. F. Hourani, 'The education of the third class in Plato's Republic' [Education], Classical Quarterly, 43 (1949), 58-60 at 60 n.I; C. Page, 'The truth about lies in Plato's Republic', Ancient Philosophy, I I (I99I), I-33 at n.2I), but none-as far as I can discover- takes the idea seriously nor considers what we should then conclude about the provision of universal education. 
T1

I'll try first to convince the rulers themselves and the military, and then the rest of the community, that all the nurture and education that we gave them seem like dreams that they experienced, or happened round them, when in truth at that time they were being moulded and nurtured deep under the ground...

Republic 4|4d2-7.

The text continues, at 4I4d-e (T2), by explaining that the young people are "born" fully equipped with full armour and other paraphernalia:

T2

Republic 4I4d6-e2

This correctly follows the pattern of all ancient autochthony myths, which are invariably about adults springing from the ground fully grown and fully armed. It is doubtless because he is thinking of his citizens being "born" when they are already trained and equipped that Socrates is prompted to invoke the Theban myth about the Phoenician king Cadmus, who sowed dragons teeth, from which an army of soldiers sprang up. ${ }^{3}$ Socrates proposes that his future citizens should believe that they were "born" when they were fully complete, with all their equipment provided, and that they should think that their education, which he has just described, was a special kind of gestation in

${ }^{3}$ Evident in the reference to the story being 'Phoenician' and "not familiar in these parts" (4I4c, see TII). 
the earth-womb, after which they were born into the open air and the light. So when the myth speaks of "birth" it means graduating to become an adult citizen. We might say it is a motif of "rebirth". 4

Nothing in what Socrates says suggests that the myth would be altered in any way, in its retelling for later generations. There is no suggestion that it is to be changed, so as to mean that the citizens are born from the earth as infants. On the contrary (as we shall see), the second part of the myth (the Myth of the Metals) indicates that it takes time for metals to be laid down in the soul. Since the children's education is what deposits metals in their souls, and the story is about how we are to understand and respond to that educational effect, it makes sense that Socrates offers the myth as a conclusion to his books on education of the young.

Part of the point of the story is to explain how important it is for the rulers to look at the abilities (i.e. metals in the soul) of a young adult at the end of the education, and assign the citizen to the appropriate duties in life on that basis. Some translators make it seem as if children are classified in infancy, but there is no reference to "children" in the Greek text. The term हैkyovoc does not mean a child. It just means a son or daughter. ${ }^{5}$ So there is no textual evidence for that idea that the "birth" mentioned in the myth is the birth of infants, or that the requirement to judge the progeny by their metals involves judging children's abilities in infancy or childhood. The story seems actually to recommend treating all children as indeterminate at birth, and delaying the assignment of classes and roles until the age of majority, when it can be done fairly according to the capabilities manifested during a period of universal comprehensive education. ${ }^{6}$

\section{Dreaming}

One key metaphor in the autochthony part of the story is that of a "dream". As we saw in TI (repeated here as T3), all the citizens will think of their education as a sequence of dreams:

${ }^{4}$ I have not located any evidence of rebirth motifs in Greek ephebic rites, but it seems plausible that there might be some. For comparable material see $\mathrm{H}$. Bloom (ed.), Rebirth and Renewal (New York: Infobase Publishing, 2009).

5 "Offspring" is the usual translation. I use 'progeny' in TI5.

${ }^{6}$ See further below (Section VII.iv) 
T3 (= T1)

I'll try first to convince the rulers themselves and the military, and then the rest of the community, that all the nurture and education that we gave them seem like dreams (ovví@ $\alpha \tau \alpha$ ) that they experienced, or happened round them, when in truth at that time they were being moulded and nurtured deep under the ground...

Republic 4I4d2-7.

I think that many readers take this to mean that people are to be hoodwinked about the true nature of their upbringing, and persuaded that it was illusory. Instead, they will be made to think something that is literally untrue - namely that, instead of the education that they actually had, they were

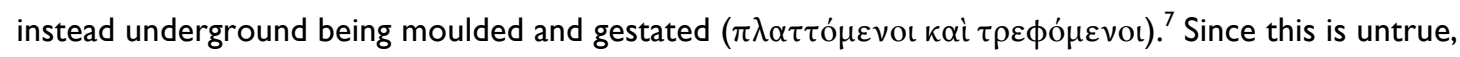
and surely they must know what kind of education they really had, this seems like deception or selfdeception. Why would they believe it? They must be brainwashed, it seems, and having been brainwashed, they will no longer be lucidly aware of who they are or how they were educated. ${ }^{8}$

That reading of the passage seems to me to be a total confusion. Here is a preferable alternative: Socrates explains that the young adults, emerging from a period of intense education for citizenship, now become lucidly aware of the true nature of their upbringing. So far from deceiving themselves into thinking that they were underground, when they know full well that they were not,

7 4I4d7. Cf $415 \mathrm{a}$ where the same verb of moulding is used, while the god is adding the metals to the stuff out of which he is making them, and of $377 \mathrm{bl}$ where the verb is used of the formation of the young child in the nursery. For $\tau \rho \varepsilon \dot{\phi} \omega$ of prenatal gestation, see e.g. Aeschylus Eumenides 665.

${ }^{8}$ R. Wardy, 'The Platonic Manufacture Of Ideology, Or How To Assemble Awkward Truth And Wholesome Falsehood' [Ideology] in V. Harte and M. Lane, Politeia in Greek and Roman Philosophy (Cambridge, 2013), I19-138, at 134 illustrates such a reading, despite observing the cross-reference to other dreaming-waking motifs. 
the best of them will come to realise - to discern in a fully rational way-that during their education they were in truth underground, and they were in a dream. ${ }^{9}$

The difference between awareness of reality and living in a dream is a recurrent theme throughout the Republic, not just here. In Republic Book 5, the lovers of sights and sounds are said to be like those who dream because they think that the "many beautifuls" are what the Beautiful is:

\section{T4}

Socrates: A person who recognises beautiful objects, but does not recognise beauty itself and can't follow if someone tries to lead him to knowledge of it, does he seem to you to be living in a dream (öv $\alpha \rho)$ or in a lucid state (ü $\pi \alpha \rho)$ ? Consider: isn't the following what dreaming

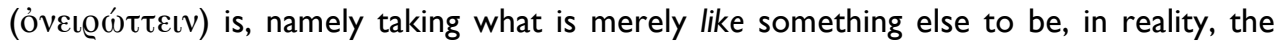
very thing itself, and not just something that is like it-no matter whether they are awake

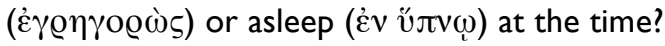

Glaucon: Certainly I would say that such a person is dreaming.

Republic 476c

T4 provides a definition: dreaming is taking for real something that is a mere image or likeness of the reality in question. Socrates contrasts the dreamer with one who knows of Beauty itself, and is aware of both it and its instantiations in ordinary things. This person (they agree) is lucid, not dreaming:

T5

Socrates: But the one who (by contrast with those people) thinks the Beautiful itself exists and can survey both it and the things that partake of it, and doesn't think that the participants are it nor that it is its participants, do you think that person is in a lucid state or in a dream?

Glaucon: Definitely lucid.

Republic 476c-d.

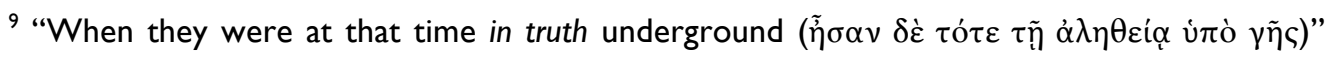
$(4 \mid 4 d 6)$ is usually taken to say that they are deceived about how things are in truth. But the term $\delta \dot{\varepsilon}$ is not answering to any $\mu \varepsilon \dot{v} v$ clause, so there need be no implied contrast between what they think and what is real. We can read the sentence to mean that when they come to think that they were down under the earth in a dream, so indeed in truth, they were actually down under the earth in a dream. 
To be lucid is to understand that the many beautiful things are like but not identical to the Beautiful itself. To be still in a dream-world is to appreciate beautiful things while still unaware that there is something else that is more real.

Now, we must ask, which state were the young citizens in, when they were undergoing the process of acculturation described in Republic 2 and 3? They were raised on good stories with fine moral examples_ "many beautiful things"-but without philosophy. They had no idea as yet that there was something else, such as the Beautiful itself. So according to the definition offered in T4, the junior citizens were in the state we call dreaming, unaware of the greater reality that is the Form itself.

It is only when they grow up — only then, if at all — that they achieve a lucid awareness that their training among the beautiful stories was all "in a dream". In fact, it is the philosopher rulers above all who will see it in this way, since they are, perhaps, the only ones who will fully understand, because they will have a clearer grasp of how those beautiful things differ from the Beautiful itself, and will see their earlier experience as a dream-like condition; whereas the ordinary citizens will never reach that level of philosophy so as to see this for themselves. The rulers above all will lucidly understand what it means to say that everything they have experienced so far took place underground, and that they were born only when they emerged from that underground womb.

We shall get a clearer picture of what $I$ have in mind if we turn now to the famous motif of the Cave, where we meet the contrast between dreaming and waking again. ${ }^{10}$ There too, Socrates speaks of the underground experience as being a kind of dream.

\section{Caves, wombs, lies.}

In Republic 6 and 7 Socrates attempts to picture the Form of the Good, and its relations to other Forms and to the sensible world, in a sequence of three images. The third of these ("The Cave") describes an underground cavern in which prisoners are chained to watch shadows on the wall, and few, if any, ever escape to discover that what they had seen was not all that there is. " The

${ }^{10}$ See below, Section IV and T6. Socrates' vocabulary at 520c6 (T6) directly echoes the vocabulary of T5.

${ }^{11}$ Republic 514a-520e. 
Cave is a large womb-like underground chamber, with a long narrow passage or birth canal, opening onto the light outside $(5 \mid 4 a 4)$. While the chains $(5 \mid 4 a 5)$ by which they are fastened to their earthy womb are not explicitly compared to an umbilical cord, their effect is rather similar, such that the movements of the prisoners are restricted, and they cannot turn their heads or move their limbs much. They see only faint images lit by the red glow of an unseen fire. Thus they live until such time as some intellectually able soul is dragged out to the light, kicking and screaming (5I5e-5I6a).

The resemblance between this underground Cave and a womb is obvious; so we only have to imagine what the earth-womb of the Noble Lie must be like for the similarity between the two images to be apparent. The idea that the Cave is a womb already appears in Luce Irigaray's reading in Speculum of the other woman, ${ }^{12}$ but whereas she focuses on the idea that it deceives and conceals, because she thinks that Plato is trying to eliminate any role for mothers in the ideal state, I do not see any negative view of the maternal role in either the Cave or the Noble Lie, when they are read as images of gestation and birth, since both ascribe all the most important formative influences on the children's upbringing to the feminine and to the in-womb experience. Even in the Cave, the transmission of shadows of the truth will become an invisible but omni-present maternal cradle of sound values and beliefs, once the philosophers have returned to govern down there, in the second part of that tale. ${ }^{13}$ Strangely, despite recognising the cave as an underground womb, Irigaray makes no connection with the Noble Lie.

The Cave has sometimes reminded people of the caves used for mystery rituals, or of the underworld in a katabasis myth, but it is not actually a katabasis: we don't first go down there and then come out; instead we come out and then go back. The Cave maps much better with the birth

${ }^{12}$ L. Irigaray, Speculum of the other woman, trans. G. C. Gill (Ithaca, 1985) (Part Two, 'Plato's Hystera'). I thank Carol Atack for alerting me to this similarity. For an accessible introduction to Irigaray's treatment see K. L. Krumnow, 'Womb as Synecdoche: Introduction to Irigaray's Deconstruction of Plato's Cave', Intertexts, 13 (2009), 69-93.

${ }^{13}$ See further below, Section IV. Irigaray perversely supposes that all the prisoners in the cave are male, although Plato consistently speaks of them as anthrôpos (which is gender-neutral). 
process: for just as we begin our lives in the womb, unaware that there is anything outside, so also the prisoners find themselves in the cave, unaware of what is outside. ${ }^{14}$

Obviously in the Cave, all children are born underground, and spend their early lives there. Some cave-dwellers will never come to realise that they were raised underground-not in the way that the philosophers realise that, once they escape from it. However, all of us can be taught a story about our gestation under the earth, or about our condition as cave-dwellers. The first ones to understand lucidly what that means, and to recognise its truth, on the basis of a true estimation of their early years, will evidently be the philosopher-rulers themselves, since they are the first or only ones to escape from the cave and realise that they had been raised underground during their youth. This gives us a clue as to how Socrates thinks that the rulers might themselves be persuaded to believe the falsehood that they are required to tell. The old problem about how to convince them falls away once we get them out of the cave. Now the philosophers will understand and endorse that myth of the earth-womb, because of what they now know-not despite what they know. It is as if they use the Noble Lie like a ladder, which they need until they have climbed out of the cave. Then they can kick it away, for they no longer need the falsehood—or rather what had seemed like fiction, when it was told as a myth to your younger innocent self, before you knew the truth about yourself and everyone else, turns out to be not mere fiction but rather a metaphor for the truth, and a source of understanding, not a source of deception.

${ }^{14}$ Those who discuss katabasis as a motif in Plato's Republic typically pick on (a) the opening word of the dialogue, (b) the cave, and (c) the myth of Er. See for example D. Clay, 'Plato's First Words' in F. M. Dunn and T. Cole, Beginnings in Classical Literature (Yale Classical Studies; New York, 1992), 113-29, at 125-9, P. Murray, 'What is mythos for Plato' in R. Buxton, From Myth to Reason (Oxford, 1999), 25I-62. On the inversion of motifs of theoria and katabasis, see A. W. Nightingale, Spectacles of Truth in Classical Greek Philosophy: Theoria in its cultural context (Cambridge, 2004), 102, 132. A more general treatment of the association of caves with altered mental states, oracles and dreaming can be found in Y. Ustinova, Caves and the Ancient Greek Mind. Descending underground in the search for ultimate truth (Oxford, 2009) (who, however, includes very little on Plato's Cave, and repeats existing views on catabasis in the Republic). 


\section{Birth and return.}

The womb-like structure of the Cave is uncannily like the earth's womb in the Noble Lie. However, there are some significant dissimilarities which need to be explored. First, whereas all the children are "born into the light" in the autochthony myth, by contrast only the few daring philosophical adventurers escape into the light from the Cave. Secondly, for those philosophical adventurers there is both an escape and then later a return, which does not obviously correspond to anything in the autochthony myth.

In fact, to be more precise, there are two bits about the philosopher's return to the Cave. ${ }^{15}$ In the first Socrates narrates what happens when the first prisoner ever to escape returns to the cave, having discovered a better world outside. Socrates describes how he returns incompetent, blind, failing in the shadow competitions, and how he is ridiculed and killed for trying to set the others free (516e-517a). This passage imagines somewhere such as Athens, where philosophers do not rule, citizens are not taught philosophy, and anyone who tries to enlighten them will be rejected and executed. This and a similar passage at $5 \mathrm{I7d}$ implicitly allude to historical events, such as Socrates' struggles against injustice in Athens.

By contrast, at 519c-520d a very different situation is envisaged. We are not in the Athens of Socrates' time, but in a wonderful city which is a community awake, not dreaming (even though it is still in the womb of the earth):

T6

And thus for us and for you the community will be run in a condition of being awake (ü $\pi \alpha \varrho$ )—not dreaming (óv $\alpha \varrho$ ) in the way that most communities are run now, by people who shadow-box with each other, and vie with each other over taking the lead, as though that were an enormous guerdon.

520c6-dl.

${ }^{15}$ On the double structure and two messages see M. Schofield, 'Metaspeleology' in D. Scott, Maieusis (Oxford, 2008), 216-31. 
Here the philosophers are required to return periodically, to govern an ideal community. This city is awake, because the people in charge of it are no longer dreaming. Yet even there, everyone still starts life in the underground womb, facing the wall and watching a shadow-show. Nevertheless, the city is "awake" or lucid, and even those who will never progress to pure intellectual studies will benefit, because they no longer live in a community that is confused and dreaming. Here, where philosophers bring wisdom and understanding to the task of governing, the people no longer box with mere shadows of justice, but with shadows that systematically and deliberately track the truth. These new shadows are carefully produced for them by thinkers who understand what justice really is. ${ }^{16}$

How will this be achieved? Presumably the returning philosophers will choose or create the models of justice and goodness for the underground society. Their shadow plays will not be like ours, determined by the whims of journalists and advertisers with no interest in what is really good. Instead their shadows will speak of justice as it really is, and of what is really good, albeit in stories and images. In the ideal state the puppets, at whose passing shadows the prisoners gaze, will be crafted by selfless philosophers who have seen the Forms, and have returned to convey the truth in a form that the people can handle. The very decision to project shadows will have been taken by rulers who want the people too see things that resemble the truth. The education underground, in the Noble Lie, and in the second stage of the Cave, is an education in likenesses, in a dream world, but in both cases the likenesses are chosen for their goodness and for their formative effect on the childish soul. They are the best there is for the young and for those who cannot aspire to the heights of philosophical vision.

There is no comparable tale of a return to the womb in the Noble Lie. But then that myth is, so to speak, confined to the underground part of the Cave myth. By Book 3 we had not yet heard of the Forms, nor that philosophy is an escape into the light, nor that philosophers would be required to

${ }^{16}$ For the equivalent task of overseeing the stories for those learning in the womb, see 377cl-6 (the first task is oversight and critique of the myth-makers); 379a (it's not the founders who make up the stories but the poets in the finished community). These points are made about the education of the young in the ideal city, but we now know that this education is informed by the knowledge of the expert philosophers who return to the cave, and overseen by them (not, as at first, by the founders). There are further questions, for another paper, about where we might find such philosophically informed poetry in Republic 10. 
ensure that the education was based on the truth. All these things must be added in Republic 7 , and much of this is added, it seems to me, in the icon of the Cave.

There is a more significant disanalogy in the fact that most of the prisoners stay underground for ever in the Cave, while in the autochthony myth everyone is born into the light. The Myth of the Metals does acknowledge the difference between those who will and those who won't become philosophers, since that is what is meant by the presence of gold in the soul, but this does not determine whether you will get out of the womb, as it does in the Cave. So we have a similar motif designating two somewhat different rites de passage, one that is leaving school and entering adult citizenship (which happens to all) and one that is a birth into philosophical enlightenment, (which happens to a few).

\section{$V$ Delivery into the light}

Are these resemblances between the two images just random, or did Plato see them, and mean us to see them too? Here are some hints that Plato meant us to see them.

First, both texts are explicitly about education. The Noble Lie completes Socrates' description of the education of the young $(376 c-412 a)$, and of the need to select the ones suited to serving as Guardians and Auxiliaries (4I2b-4l4b). As we have seen, the story they must believe is about their education and nurture (the education just described in Republic 3). Birth from this womb comes at the end of all that. ${ }^{17}$

Similarly, in Republic 7 Socrates explicitly claims that the Cave will represent our experiences with respect to education and the absence of education:

Next, I said, picture our condition ( $\varphi v ́ \sigma i \varsigma)$ with respect to education and lack of

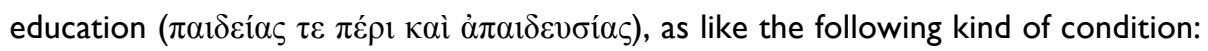
take a look at some people in a kind of underground cavernous dwelling...

\footnotetext{
${ }^{17}$ See above, Section I and below Section VII.iv.
} 
Socrates speaks of "our education", because he is thinking of the condition of people in general, in non-ideal cities. But by $519 \mathrm{c}-520 \mathrm{~d}$ we find that this describes the situation in the ideal city too. So both motifs are about the perfect city's provisions for educating the young in the womb of the earth.

Secondly we should note the many birth-related motifs in the Cave, and in the other parts of Republic 7 that are about educating the philosopher kings. At 5I5e6-5I6al, a prisoner is "released" and dragged out of the cave into the light, ${ }^{18}$ and at $52 \mathrm{lc}$ Socrates asks us to consider "how someone will lead them up to the light, as they say some people come up out of Hades to the gods". 19 In the Noble lie, at $4 \mid 4 \mathrm{el}-2$, the earth-mother unfastens and spews out the neonates, at the end of their education. ${ }^{20}$ Some of the expressions about emerging into the light after a period of gestation are parallel to the terminology that Plato uses of the delivery of a child in the Timaeus. ${ }^{21}$ Perhaps we should also see a reference to the rotation of the child in the womb, ready for birth, in the idea of studies that can "turn the soul", to prepare it for birth into the light. ${ }^{22}$ We are reminded (though not explicitly) of Socrates' self-description of himself as a midwife. ${ }^{23}$

The trainee philosophers are to be delivered into the light by means of an education that reveals a whole new world outside the cave. So the Cave is not just about politics. It is not just about needing philosophers to return to run the state. They must also return to educate the young. Who is it that will first force a youngster to turn and shed his chains? Who will drag him out into a world he

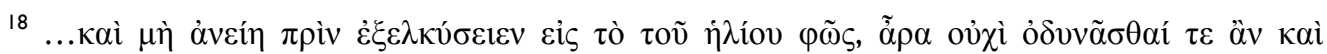

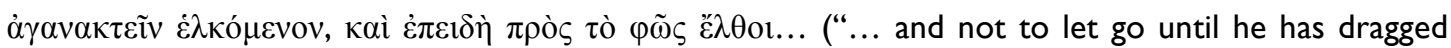
him out into the light of the sun, wouldn't he find it painful and distressing being dragged along, and when he got near to the light ...”).

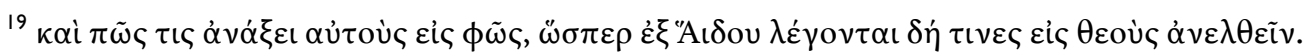

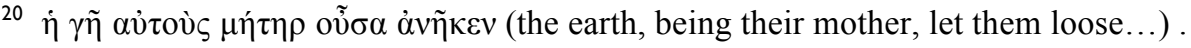

${ }^{21}$ E.g. Timaeus $91 \mathrm{~d}$.

${ }^{22}$ 524e-525a ( $\left.\mu \varepsilon \tau \alpha \sigma \tau \varrho \varepsilon \pi \tau \iota x \omega v\right)$. Cf also Aristophanes' speech at Symposium 190e3, where Zeus rotates the heads of the newly halved humans.

${ }^{23}$ Theaaetetus 150b and passim. There Socrates is delivering his pupil's unborn theories, whereas in the Republic the pupil herself needs to be delivered. Midwives are still needed, however. 
had no desire to see? Surely a philosopher-midwife who returns to the dream world to forge the gold in the soul of those capable of philosophy, and bring them out into the light, where they can flourish.

\section{Ideological inhibitions}

On the basis of these parallels with the Cave, we are now in a position to challenge several dominant ideas about Plato's ideological aims in recommending the use of the Noble Lie. First we shall consider what makes Socrates embarrassed about his proposal. Is there something that would be difficult for his listeners to accept? If so, what?

VI.iWhy is it hard to believe?

Before blurting out his plan for a founding lie, Socrates expresses great hesitation about what he is about to propose. This is the exchange that comes immediately before TI.

T8

You're hesitant about telling it, by the looks of you, he said.

You'll see that it was perfectly reasonable to be hesitant, once I do say it, said I.

Tell away, he said, and stop worrying.

Tell it I shall, then-though I can't think where I'll get the courage nor the words to do so-

$4 \mid 4 c 8-d 2$

Recent interpreters have generally taken Socrates' embarrassment to be occasioned by the need for falsehood. ${ }^{24}$ Socrates had just spoken of pragmatic justifications for occasional uses of falsehood. The relevant text is T9, which also refers back to an earlier discussion of lying (382a-d), in which Socrates had suggested that lying is acceptable only in sub-optimal situations. It seems

${ }^{24}$ A counter example is Wardy, 'Ideology', 132, who takes the problem to be purely the practicality of deception, as though Plato had no qualms about the use of falsehood. (My present paper, born during the oral discussion of Wardy's paper at its first outing, counters both views). 
surprising, then, that lying should be required in a perfect society. ${ }^{25}$ But is it this or something else that makes Socrates embarrassed? Socrates makes four remarks about the difficulties that he foresees in trying to convince people, none of which mention falsity as a problem. Let us look at the relevant passages.

First, in conversation with Glaucon, Socrates mentions that the best situation would be if we

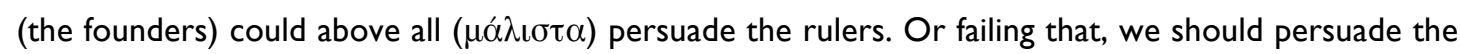
rest of the city.

T9

So shall we help ourselves to a device, I said, in the form of one of those fictions we were talking of earlier, that grow up in times of need? Shall we fabricate a noble one, to convince above all ( $\left.\mu \alpha \lambda^{\prime} \iota_{\iota \tau} \alpha\right)$ even the rulers themselves? But if not, the rest of the community?

4I4b7-c2.

In the preceding passage, Socrates had just distinguished, within the Guardian class, between "Rulers" and "Auxiliaries". ${ }^{26}$ So saying that we should "convince above all the rulers" means the rulers as opposed to Auxiliaries and others. Convincing just the others is clearly second best.

A moment later, just after T9, he makes a similar remark, quoted already in TI

T10 (= T1, T3)

I'll try first to convince the rulers themselves and the military, and then the rest of the community, that all the nurture and education that we gave them seem like dreams that they experienced, or happened round them, when in truth at that time they were being moulded and nurtured deep under the ground...

$4 \mid 4 d 2-5$

${ }^{25}$ See M. Schofield, Plato: Political Philosophy [Plato] (Oxford, 2006), Chapter 7, esp 297-303. Schofield argues that the proposal is indeed shocking for this reason.

${ }^{26} 4 \mid 4 a-b$. 
In TI0, as in T9, Socrates says that he will try to convince the rulers. Here he says $\pi \varrho \hat{\omega} \tau o v$

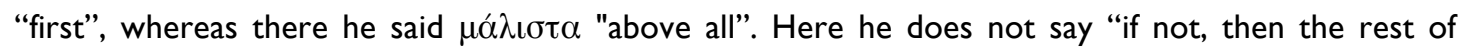
them," as he did in T9, but "first these and then the rest". Since TI0 comes just after T9, it is reasonable to think that these express roughly the same thought; ${ }^{27}$ although the second is slightly more ambitious, he still only commits himself to attempting this, and there remains a possibility of failure. Nevertheless the common idea in both cases is that he should work in this order, to persuade the rulers first and foremost, if the project is to succeed.

Between T9 and TI0 comes our third remark. Socrates observes that the story he will fabricate refers to events that happened long ago in far away places (according to the poets), but which no longer happen around here. We don't find people being born from the earth "here with us" ('亡े’’ $\dot{\eta} \mu \hat{\omega} v):$

T11

Like what? he asked.

Nothing novel, I said, but something Phoenician in origin, that once occurred widely, so the poets say and have us believe, — though not something that has ever arisen in our own society and I don't know that it ever would- but vast in its capacity to command conviction.

$4 \mid 4 c 3-7$

Again Socrates makes no mention of falsity or historical implausibility as reasons for disbelief. Although he claims that such events no longer occur, that apparently makes the story more convincing, not less so. Much of this may be intended as cynical jokes at the expense of Athens. ${ }^{28}$

Finally, having recounted the myth, Socrates worries again about its uptake. He asks Glaucon to think of a mechanism for installing the myth:

\footnotetext{
${ }^{27}$ See further below, Section VIII.

${ }^{28}$ For Athenian autochthony myths see e.g. Thucydides II 36, Plato Menexenus 237b; N. Loraux, The Children of Athena [Children], trans. C. Levine (Princeton, 1993).
} 
Do you have any device whereby we could get this myth endorsed?

Nothing, he said, that would do the trick for these people themselves. But that their sons and subsequent generations and all the rest of the people who came after would.

But that too, I said, would contribute towards making them take more care for the community and for each other.

By "these people themselves", Glaucon means the first generation. He thinks that one might fail to convince the first generation, but succeed in establishing the myth among subsequent generations.

Why does Glaucon think that? Most readers seem to assume that he means that later generations will be ignorant, and this will facilitate belief. They assume that the first generation will be unpersuadable because they know full well that they were not born of the earth, whereas persuading a generation that did not know the facts would be easier. If the relevant facts are in an inaccessible past known only from myths, the later generations could be deceived.

This interpretation of Glaucon's suggestion presupposes (a) that the "birth from the earth" in the myth refers to a literal birth and involves denying biological facts about one's birth in infancywhereas I have argued that it means the transition to adult life - so that what inhibits belief is knowledge of biological facts; and (b) that the myth tells only of the birth of the first generation, not every generation, since Glaucon's suggestion would make no sense if the myth is about where babies come from and is told of every generation. Obviously, if everyone knows that human babies are born from human mothers here and now, it would be no easier to persuade the second generation than the first that they were born some funny way.

In Section VII.i below I present the case against the first-generation-only assumption. For now, however, I shall develop my alternative proposal, based on the assumption that what hinders belief is not knowledge of biology, or history, but ideology, the existing beliefs of Socrates' audience about how social status is transmitted. Perhaps the hard bit is not birth out of the earth, which 
conflicts with biology, but the radical message about breaking down inherited privilege, which conflicts with convention. For sometimes the truth is harder to believe than something false but comfortable.

Why would Glaucon suppose that later generations would more readily believe, then, if the difficulty is ideological? Several charitable and less charitable explanations are compatible with my reading of the text. Least charitable would be to suppose that Glaucon simply misunderstands, imagining a first-generation-only myth like the existing ones. More charitably, he may be correctly noting the quite general truth that stories learned at mother's knee are more readily assimilated. But Socrates' response at $415 \mathrm{~d} 2-3$ ("I kind of get your point”) suggests that Glaucon's thought is one that he too could endorse, at least in irony. One option, again not very attractive, is that Socrates supposes that major ideological changes typically take more than one generation to become embedded, and that first you must persuade a few and build up from there. Or, more interestingly, he may be anticipating what will actually come about, which is that the problem will dissolve even before we need to persuade the first rulers. His question implied (perhaps ironically, but realistically on the surface) that there would be a difficulty, and it is no surprise that Glaucon agrees, because, as things stand, you would indeed expect the rulers and aristocrats to be the least ready to give up the idea of inherited privilege; but Socrates himself knows that the problem will have dissolved once we reach Book 7 of this text, by which time we shall understand who these rulers are and what they will believe about themselves. "But this will turn out in whatever way the omens take it", he says: a mockserious utterance which could be heard to say that it is in the lap of the gods whether the myth gets believed. ${ }^{29}$ But surely Socrates really means that the omens are good. It will be a success-we just don't yet have the resources to see why.

VI.ii Some existing accounts of the ideological content

One obvious motive for recommending the autochthony myth is to promote loyalty to the land and its inhabitants, as Socrates explicitly observes:

${ }^{29}$ I disagree with recent interpreters who take $\phi \eta \dot{\mu} \eta$ here to be a reference to the popular voice (as recommended by J. Adam, The Republic of Plato (Cambridge, 1902), ad loc.). Rather I take it as one of Socrates' typical hints at the need for divine assistance. 
T13

... so now, just as they would about their mother and nurse, they will engage in deliberation about the land $(\chi \omega \hat{\omega} \alpha)$ in which they dwell and defend it, should anyone threaten it, and they will take thought on behalf of their fellow-citizens, on the basis that they are siblings and earthborn.

Republic 4I 4e2-5 $5^{30}$

This is not a new ideology. It is the traditional use to which such autochthony myths were put in the ancient world, although we can now see that Plato provides a much richer significance to this motif of unified devotion to the same mother, since his myth is actually about deliberately dividing the classes. Unity across that hierarchy of adult citizens will be fostered by ensuring that the children have all grown up together, sharing the same womb for years, no matter what class or role they are to occupy as adults, as we shall see. ${ }^{31}$

The idea of loyalty and commitment to the country is all that most scholars in anglophone traditions notice in the myth, doubtless because that is the motif that is familiar from the historical parallels, and because Socrates (perhaps ironically) borrows that motif and appears to endorse it. ${ }^{32}$ But if that is what the myth is about, what is the warrant for deception, in a city where good reasons could be given instead? Equally, such familiar themes would not explain the extreme hesitation that Socrates expresses about making his proposal. ${ }^{33}$ This leaves several strange mysteries unanswered.

By contrast in the French tradition, thinkers have suspected a gender agenda. Nicole Loraux, for example, takes Plato's myth to be replicating the Athenian autochthony myth, which she thinks

\section{${ }^{30}$ Continues T2.}

${ }^{31}$ See further in Section VII.iv. See also $519 \mathrm{e}-520$ a for a similar ambition in the requirement to get the philosophers back down into the cave, "making them give and take with each other the benefits that each can provide to the others," for the sake of unifying the community. The return to the cave is the mirror image of the birth from it: both plunge all classes into a shared environment from which no privilege or elitism must remove them.

${ }^{32}$ See Schofield, Plato, 286.

${ }^{33}$ See above, Section VI.i. 
was designed to eliminate maternal contributions to Athens's grandeur. She infers that Plato was doing the same for his city, although, surprisingly_as also with Irigaray—, she seems never to have explored this particular myth in any detail. ${ }^{34}$ She takes it for granted that Plato was trying to devalue the role of real mothers in his state. ${ }^{35}$

While it is certainly possible to use a myth, or indeed a political system, that displaces the need for traditional mothers, for misogynist purposes or to promote a patriarchal ideology, I don't think that we should read Plato's Republic as an attempt to do that. If Loraux is right that Athens deployed such a myth as a way to secure its patriarchal system, surely that is the opposite of what Socrates wanted. Would Plato be endorsing, as opposed to ridiculing, the Athenian ideology that condemned Socrates to death for engaging in philosophical enquiry? Granted, Socrates' myth would indeed remove the birth-mother's role in raising the child, but it also eliminates the genetic father. Since it does not negate the importance of feminine roles for nurturing the infants, but simply reassigns those roles to state mothers and nurses, Socrates seems to be accepting the importance of mothers and the place which a boy's mother holds in the heart of the adult citizen, which is what underlies his claim that the grown men will feel such absolute loyalty to their common "birth" mother, the earth $(4 \mid 4 \mathrm{e} 2-5, \mathrm{TI} 3){ }^{36}$

${ }^{34}$ She regularly cites the Menexenus and sometimes mentions the Noble Lie in passing: Loraux, Children, 240 notes the need for a treatment of the Republic but does not attempt it herself. There is an attempt in B. Rosenstock, 'Athena's cloak: Plato's Critique of the Democratic City in the Republic', Political Theory, 22/3 (1994), 363-90 (pages 365-6 on the Athenian autochthony myth and 370 on Plato's own use of that motif), who uncritically follows A. Saxonhouse, 'Myths and the origins of Cities: reflections on the autochthony theme in Euripides' lon' in P. J. Euben, Greek Tragedy and Political Theory (Berkeley, 1986), 252-73 and N. Loraux, The invention of Athens: The Funeral Oration in the Classical City, trans. A. Sheridan (Cambridge Mass., 1986).

35 Loraux, Children, vid. N. Loraux, Les Enfants d'Athéna (Paris, 198I), especially p.I3. Compare Irigaray's reading of the Cave (above, Section III).

${ }^{36}$ The text is gender-neutral here, and will obviously apply to female earth-borns too, but I take it that Socrates has in mind his own experience of the way a young man responds to an insult against his mother. 
I would therefore resist the idea that Plato's aim was to deny the importance of mothers. In Plato's myth the "earth" is pictured as a mother precisely because mothers are so highly valued and influential. Earth's motherly womb is the crucible where the citizen's virtues of body and soul are formed. Her influences are what make the citizens perfect. Recognising that this myth is about education, not biology, makes the role of mother earth even more important.

Besides these two readings, the standard one in anglophone reception of Plato is probably that associated with Karl Popper. ${ }^{37}$ On this reading Plato's aim is to deceive people into accepting and preserving a class system that is not natural but is falsely presented as if it were. The Popperian reading assumes that the myth of the metals is a lie which is pragmatically necessary but does not reflect any facts in nature. Interpreters who take it this way differ in how deceptive the lie is, from regarding it (as Popper did) as pure racist propaganda with no basis in truth, to regarding it as a "pharmacological lie" propping up difficult truths. ${ }^{38}$

VI.iii A more subversive message: Eliminating hereditary inequalities, parental influence and educational privilege.

In reading Plato's political proposals, it is always better to suppose that he is challenging the prevailing ideology. Indeed, finding that the proposal is radical and strange would better explain Socrates' hesitation in speaking of it. Perhaps he subverts an existing autochthony motif to found a new just society instead, one in which human parentage has no bearing on status, and all gender roles are removed, replaced by equality of opportunity for all, maximum social mobility and gender-neutral career structures. Surely he is rejecting, not adopting, Athenian ideology.

If this is right, what is new about his proposed ideology will be the idea that people start life equal as infants, and are not to be classified until they have had a chance to show their aptitudes. The idea that a child's status and its future role in society must not be influenced in any way by its birth or parenting should be mind-blowing to Socrates' audience. Plato abolishes status by birth. There is to be no hereditary peerage, no royal family, no hereditary shoemakers, no inheriting of a family business. A

\footnotetext{
${ }^{37}$ K. Popper, The Open Society and its enemies Volume I: Plato (London, 1945).

${ }^{38} \mathrm{~J}$. Hesk, Deception and Democracy in Classical Athens (Cambridge, 2000), I53-I 56.
} 
shoemaker's son must become king if he is fit to be king. He must not be left trying to make shoes. Nor must a king's son be asked to make political policy if he is better at cobbling.

Plato's current readers clearly struggle to see how radical this project is, and in what way it is radical, compared with either a traditional aristocratic ideology or the democratic ideology of Athens. Plato is looking for a better system, to ensure that nothing affects your chances of a powerful position except political wisdom and aptitude. Democracy, which ignores political ability, is as much under attack as aristocracy, since democracy is itself a hereditary peerage system. ${ }^{39}$ What Socrates aims for is equality of opportunity for all combined with distribution of responsibilities according to ability.

So Plato's myth is shocking, hard to believe, something he hardly dares to utter, because instead of preventing social mobility it enables it. Everyone eventually acquires a class, but the classification is postponed until the moment of parturition from the education system. Its provisions are somewhat challenging even for democratic Athens, and very challenging for Plato's oligarchic relations (who are Socrates' imagined listeners). This easily explains Socrates' hesitation, because the story challenges all existing political agendas, whether aristocratic, oligarchic or democratic.

Meanwhile it is by no means clear that there is any genuine falsity in it, other than the picturesque metaphors. The message that it delivers is surely meant to be true. ${ }^{40}$ Yet the truth that it contains could still be hard to believe, for anyone raised with conventional expectations about birth and inherited status. This would be a sufficient reason for thinking that the rulers will need to be persuaded. Perhaps there is no better or truer way to persuade them of the truth than by telling stories?

VI.iv Hierarchy by educational attainment not by birth.

The Myth of the Metals elaborates on the idea of a birth from the womb of the earth by suggesting that students develop different metals in their soul during their underground gestation, so that by the time they are "born" some are imbued with copper, some with silver and some with gold.

39 Contrast the point at Menexenus 238c-d, where the speaker calls democracy an aristocracy-not on the grounds that political influence is inherited, but on the grounds that the people choose the best people as leaders.

${ }^{40}$ See further below, Section VIII. 
T14

But still, you should go on and listen to the rest of the myth. "For all of you who live in this community," we in our myth-making role shall say to them, "you are all brothers; but the god who moulded you, those among you, on the one hand, who are capable of governing, he mixed gold into the birth for them, making them highest in honour; those who are auxiliaries, secondly, silver; but iron and copper for the agricultural and other manual workers."

4|5al-7.

This provides a mythic aetiology for differences in the citizens' aptitudes and career prospects. Since, as we have seen, "birth" is the birth into citizen life at the end of school education, this is giving an account of the differences in the citizens' souls by the time they enter adult life. The rulers are required to sort the citizens according to their metals rather than by any system of privileges that would advance an unqualified citizen, or demote one who was more able.

This part of the myth calls upon many fruitful images such as the idea that creatures that lived and grew underground would naturally absorb the minerals of the earth (such as those evident in stalactites and the salts and metal ores in the mines), and the idea of selective absorption, each soul exclusively admitting one pure metal so that they come out fitted for one kind of occupation. These motifs draw upon metaphors from chemistry and geology. At the same time there is the continued motif of motherhood and nurture, the idea of an embryonic self nurtured with moral training and intellectual development as well as material sustenance. We can imagine that mother earth is sensitive to the emerging metals in the child's soul, so that each emerges, at its second birth, suitably trained for its own best career.

Thirdly there is the image of divine creativity. Socrates says that it is "the god" who mixes one or another metal into the child's soul. ${ }^{41}$ Why a god? One effect is to specify that the process cannot be engineered by human agents. Which metal the child gets is determined externally, "by god". 42

\footnotetext{
${ }^{4 I} 4 \mathrm{I} 5 \mathrm{a} 4$. I.e no one gets mixed metals, as noted by Schofield, Plato p.290.

${ }^{42}$ See further, Section VI.iv.
} 
The Guardians can neither cause a student to absorb gold, nor can they assume that she will become gold because she had gold parents. Their only question must be whether she has gold in her soul, by the time of her birth into citizen life:

\section{T15}

Given that you are all related to each other, all of you will for the most part beget others like yourselves, but there will be times when silver progeny will be conceived from gold, or gold from silver, and all the other metals from each other similarly. Hence the god's first and most emphatic message to those who govern is that there is nothing about which they will be better guardians, and nothing that they will guard more carefully, than the progeny, as to what exactly has been mixed into their souls.

4I5a7-b7.

The Myth of the Metals is designed to ensure that citizens are not misclassified by who their parents were (4I5a-c). This is the most important instruction that the god gives, because the city will be destroyed if they ever make a mistake $(4 I 5 b) .^{43}$

Given this rationale, Plato must mean that genetics cannot guarantee the transfer of metal from parent to offspring. Does he just mean that inheritance is fallible (and the failures must be picked up correctly), or that nothing is inherited? Either position is compatible with what Socrates has in mind, since the important point is that what matters for who you are is not who your parents are but what you are suited to. The only interpretation that cannot be right is Popper's view that class is based on inherited racial characteristics.

How exactly you become prone to absorb silver rather than bronze is under-specified in the myth, except that the work is attributed to "the god", which, as noted above, is a way of denying that it can be altered by human intervention. ${ }^{44}$ Some passages imply that offspring typically resemble their

\footnotetext{
${ }^{43}$ A similar warning is given about the rules of marriage at $546 \mathrm{~d}$. See note 52.

${ }^{44}$ See TI4.
} 
immediate parents (e.g. 4I5a7-b2, TI5), ${ }^{45}$ while others warn the Guardians that nothing stops their children from having something quite different (4I5b7-c8). These are not, of course, contradictory.

In any case it is clear that Socrates' main point is the negative one: that one absolutely must not rely on the mere probability. ${ }^{46} 4 \mathrm{I} 5 \mathrm{a}-\mathrm{c}$ instructs the rulers not to cut corners: they must test for the metal, not go by the parentage. They might be tempted to use parentage as a rule of thumb, or to promote someone they think was their own son or daughter. In reality, as we later discover (460d, 46Id), the society will not keep track of the parentage of Guardian offspring-a provision which effectively removes the latter temptation provided the scheme is correctly followed.

Whether Plato thought that abilities were mainly inherited, or mainly random, the earthwomb is clearly provided to ensure that everyone has an equal chance to acquire and develop talents, and manifest them, before being assigned to their life-plan. We need not determine exactly what is due to nature and what is due to nurture, providing that we understand that the nurture is designed to ensure that no one is set up to fail due to unequal chances.

To sum up then, Plato's position is that whatever hereditary influence there may be on a youth's capacity to absorb this metal or that, it is unreliable and must be ignored as regards educating her for future life (for which nothing but her actual abilities count). Also we should not confuse inherited ability with inherited privilege, which is where people gain advantages that do not match their ability (whether inherited or not), simply due to belonging to some privileged family.

\section{Further details on inheritance and class}

My reading differs in several ways from the received readings. Here, in Section VII, I turn to some smaller questions of interpretation that need to be addressed, in order to engineer a more complete reversal of our expectations and responses. Finally, in Section VIII, I shall step back once more to note the advantages of discovering in the Noble Lie a myth that befits a state which claims to be awake and not dreaming, and one which is trying to be completely just in its distribution of work.

45 There are other ways of reading this passage, which could mean that all the children are mainly very similar, apart from the metals, due to all families sharing a common genetic pool.

${ }^{46} 4$ I5b; cf 459d-460b. 
VII.i Is the Myth of the Metals about all generations or just the founding generation?

As noted above, there are two readings of the myth of the metals. ${ }^{47}$ Either it is a story for every generation about their own birth, or it is a story for every generation about the birth of a founding generation. ${ }^{48}$

The first-generation-only reading may seem easier because other ancient myths of autochthony, such as the Cadmeian myth, were first-generation-only myths. Also, as we saw above, many assume that this is why Glaucon thinks that the second generation would more readily believe it. ${ }^{49}$ Such readers might also appeal to the fact that after explaining the myth, Socrates goes on to speak of leading out his band of new citizens to find a place to colonise ( $415 \mathrm{~d}-\mathrm{e})$. This evidently refers to a one-time event in the first generation.

However, it would be a mistake to think that this motif, of "arming them and leading them to find a place to colonise" has any bearing on the meaning. Socrates does indeed pretend, throughout the Republic, that he and his friends are founding the city, setting up its first rulers, delivering instructions for how they should go on. But the Noble Lie is part of the instructions for how to go on. Just as the first generation will be taught that the "education that we gave them" was all a dream (4I4d), so also the next generation need to be told that the education they received was as much a dream as that of the first, and was where they acquired their metals. All the difficulties with this idea dissolve once we see that the myth is about a rite of passage into adult life, and is about assigning young adults to their careers by aptitude, not birth.

Meanwhile the first-generation-only interpretation suffers from a fundamental flaw, which is that we have no real interest in whether the first generation were once defined by the metals infused into their soul. What matters for the survival of the city is that today's generation must be classified by the metal in their soul, not by their ancestors' metal. The metals must be checked for each citizen, in each generation, because it may not match what their parents had. A myth that declares that the

\footnotetext{
${ }^{47}$ See above, Section VI.i.

48 The founding-generation-only view appears in e.g. Schofield, Plato, 287, 303; Rosenstock,
} 370.

${ }^{49}$ Schofield, Plato, 287-8. 
first generation was sorted by metals has no use whatever, least of all if it means (as in the old autochthony myths), that privilege runs in families from the privileged ancestors. ${ }^{50}$

So although the ancient myths that Plato parodies may have been first-generation-only myths, Socrates evidently needs to invent a new version that is repeated for every generation.

\section{VII.ii Is the eugenics programme relevant to inherited metals?}

Besides the metals (which represent generic aptitudes), citizens will show various degrees of talent or excellence in their roles. Here too, it seems, sons and daughters must typically resemble their parents, since the eugenics programme that Socrates devises (459d-460b) is designed to raise standards in this respect, especially to get more of the very best Guardians-not more Guardians, but more of the talented ones and fewer of the less able. To that end the most talented Guardians are awarded more sexual liaisons, to increase the offspring from that stock at the expense of others in the same class.

The idea is not that those chosen Guardians will make more silver or gold babies. Socrates does not want to increase the number of silver or gold babies: stable numbers must be envisaged in each class, since he aims at a stable population overall. ${ }^{51}$ So the selective breeding programme is not about increasing the chances of getting gold-any old gold-, but rather increasing the chances of getting someone at the top of their class, and reducing the chances of getting the mediocre ones, and thereby raising the general standards of talent. ${ }^{52}$

${ }^{50}$ Compare the "digression" in the Theaetetus (esp. 174e- I75b), where Socrates portrays the true philosopher as unmoved by conventional claims to status by wealth, birth, or the prestige of one's ancestors generations back. Thanks to an anonymous OSAP referee for this nice point. I shall have more to say on the proximity of the Theaetetus to the Republic and the Phaedo in my forthcoming book on Plato on Knowledge and Truth.

$51460 a$.

52 The risk from not following the selective breeding programme is that, due to inferior breeding, the rulers will become less good at distinguishing the metals in the souls (546d), which in turn leads to (i) misclassification of the young and hence (ii) muddled classes, leading to (iii) corruption of values among the rulers. 
Being a talented Guardian is not a matter of having a different metal, since the metal is what defines her class, not her rank in it. Maybe exceptional talent might consist in having more of the relevant metal, though nothing in the text suggests that. But even if that were so, there is still no conflict with the main message of the Noble Lie, which is that the presence of one metal or another, let alone how much of it, is significantly unpredictable. Whether or not breeding for excellence can be done, because children often take after their parents in virtue as well as metals, it remains true that the citizens must always be classified by their actual abilities, not by what you hoped they would be like, given who their parents are.

VII.iii Are the metals due to "nature"?

Socrates sometimes speaks of people having a "nature", or "growing gilded or silvered". 53 Because of the double birth, it is unclear what this means. In the autochthony metaphor, "birth" is leaving school, so one's "nature" (phusis) at that birth would be the adult condition, not the condition when the child entered the earth-womb. So when some earth-born citizen is said to have grown silvered or gilded (4I5c3-4), that does not mean that she started her education with a phusis already silvered or gilded. Rather, that is being denied. When she enters the earth-womb at bio-birth, the god has not yet infused her soul with any metal at all.

Were the infants already naturally differentiated, such that some tend naturally to absorb bronze and some to absorb silver or gold? Or is it the god's whim which gets which? Here no answer is specified, I think, and perhaps none is required. Plato's point is that any nature that the child might have at bio-birth is quite opaque to her parents and to the rulers. They can only see and judge the nature of the developed adolescent, when her education is complete, and then no prejudice must deny that one who entered the education system without any evident gold or silver may well have come out finely gilded with intellectual achievements or military prowess. By the time of citizen birth, each citizen has acquired a phusis. We neither should nor can ask what its phusis was before its gestation, if it even had one. ${ }^{54}$

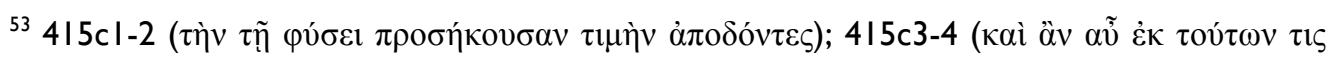

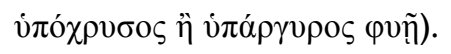

${ }^{54}$ For the term phusis used of our educational condition see also T7 above. 
It would be wrong to suppose that when Socrates describes the phusis required in a Guardian (374e-376e), he means her nature prior to education. The point of asking (at 376c) how to educate them, to get that result, is to work out how the city is to instill and develop such a phusis in them by the time they are born as citizens, through gestation in the womb of a state education. There is no contrast between "nature" and "education" here, because the Myth of the Metals changes the period during which you acquire your nature. We are no longer to think that the nature is complete prior to infant birth. ${ }^{55}$ It gets completed and differentiated prior to citizen birth. "Nature" is one's native character at the time of nativity, whichever 'birth' is at issue in a given context. In this context, the relevant birth is citizen-birth, as defined by the myth, and not bio-birth. ${ }^{56}$

55 It might be held that the absurdity (to our eyes) of sorting newborns was less obvious to the ancients. But I sincerely doubt that Aristotle was thinking of sorting human children, when he said, at Politics 1254a23, that some things (neuter) are differentiated for ruling or being ruled right from birth. Since he is talking at least partly about the natural rule of man over beast, or predator over prey, presumably these are just things that differ according to whether they belong to the dominant species or not (which is indisputably apparent at birth). And indeed, Aristotle has already granted that however much nature "tries" to differentiate the bodies of slaves and free correctly, in reality there is frequently a mismatch (1245b27-34). So any infant sorting by bodily appearance would be as risky and inappropriate for Aristotle as it is for Plato.

${ }^{56}$ The same reading can be applied throughout to the references to the philosophic "nature" in the Third Wave section, 485-502, though here is not the place to explain this in detail. But note $485 \mathrm{~d} 3-4$, which refers to the philosophers' desire for truth from the word go (from when he was a

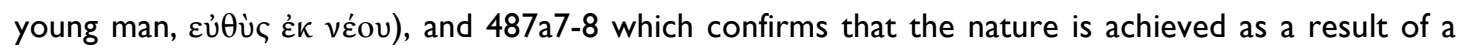

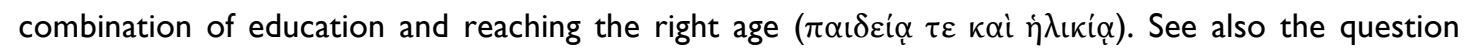
whether women are invariably inferior at some or all tasks $(455 c-d)$ where we are also considering what adult women are good at after being educated, and whether they too can acquire a philosophical nature by being educated in the same way as the men. 
VII.iv Do all the citizens undergo the elementary education described in Republic 3?

A largely unchallenged tradition assumes that Socrates describes an education that is for the Guardian class only, and that little or no provision is made for the education of the workers in the ideal city, other than apprenticeship in their craft. The case is made in a short article from 1949 by G. F. Hourani. ${ }^{57}$

As Hourani notes, if true, this would make class mobility of the kind described in the Noble Lie impossible in practice, despite Socrates' insistence on its importance. ${ }^{58}$ We must conclude then either that Plato never really meant that social mobility was crucial, and made no provision for it (in which case we might wonder why he provides the Noble Lie at all), or that it is false that he made no provision for it. The latter seems the more plausible and charitable hypothesis, and hence, if we have to conclude that Plato made some mistakes, it is more plausible that he made some less serious mistakes (such as, for instance, sometimes forgetting that the education is intended for all classes, not just Guardians) and not the more egregious and politically inept mistake of denying children the chance of becoming what they should be, and thereby destroying the justice of his city, and retaining the old hereditary privilege instead of the novel meritocracy that was his pride and joy.

We should not, of course, be surprised that Socrates starts with a question about how we should educate our Guardians. For initially, before the meritocratic system has been explained, it looks like education for ruling is what is required, above all. But once we meet the Noble Lie, we realise that this education that instils gold, silver and bronze into different souls must be an education for all, since that is how those minerals are distributed, in the process of nurturing underground. So Socrates' initial question, at 376 c, was “how shall we bring these people up?". It follows Socrates' initial description of what a Guardian for the ideal state must be like. These well-trained civilised young people need an education that produces that result. Book 3 investigated what education that is.

Yet although we started by asking how to make Guardians, and indeed we finish Book 3 with that question, the effect of adding the Noble Lie and the Myth of the Metals at 4I $4 \mathrm{~b}$ is to round that account off by showing that actually, remarkably enough, this underground womb is designed to

\footnotetext{
${ }^{57}$ Hourani, 'Education'. See above note 2.

${ }^{58}$ Hourani, 'Education', 60
} 
nurture all the citizens together and develop skills that differentiate them from each other. That must be so, because it is in that womb, during that education, that all the citizens progressively absorb their metals, and it is from there that they emerge as citizens and take up their various careers. The Noble Lie reveals that all citizens enter the womb undifferentiated, and leave it differentiated. So there were no readymade Guardians at the start. There were just infants.

It stands to reason, of course, that an elementary education in good stories, poetry and music, is essential for a bronze child just as much as for a silver one. In fact the tripartite soul analysis makes it clear that all three parts of the soul-and likewise, therefore, all three classes in the stateneed to be willingly in accord with reason and amenable to rule by collaboration and consent rather than oppression and control. It is this harmonious accord that constitutes the virtue of sophrosune in the state and the soul. ${ }^{59}$ It would make no sense, then, to leave children of the third class exposed to stories that encourage appetite, depravity or any other vices. The idea that ill-educated masses would be deleterious in the ideal state is therefore not just an a priori hunch. ${ }^{60}$

Most of Plato's discussion is about how to manage the lives of the Guardians. Certainly, when it comes to explaining how Auxiliary women can work alongside men in the military, provision must be made for their children to be removed to a nursery (46Ic). In making this provision for women to combine reproduction with a military career, Socrates says nothing whatever about the provision for children of other mothers. The premises deployed in Socrates' argument about gender equality are not peculiar to the skills or duties of Guardians. Indeed, Socrates notes that the same argument applies to so-called women's work such as weaving, making sacrificial muffins, and preparing boiled veg $(455 c)$. Based on the section on women Guardians, there is no reason to go either way on

\footnotetext{
${ }^{59}$ Republic 43 Id-e.
}

${ }^{60}$ For evidence of the inclusion of all classes, see $423 c-424 \mathrm{e}$, where Socrates says that the crucial thing is to give the community a good start, "for if you maintain a good nursery and education system ( virtuous circle of ever improving education from generation to generation. Among the major worries are popular music and other forms of indiscipline. So (424e) we have to get the children ("our children", meaning the ones in our new community) playing in the right way from the start, and learning to respect their elders and so on. 
whether the city's communal crèche is also for the children of workers. Yet clearly the myth of the earth-womb strongly implies that all of them are installed down there in the womb together from infancy, absorbing whatever they can from the fine educational provisions that Socrates has described.

Given that Socrates is primarily interested in how to train Guardians for roles in politics and defence, it is hard to discover in detail how or when the bronze children would begin on their apprenticeship for their designated craft. $^{61}$ How would this fit within the single common womb of development, where some are acquiring bronze, while others are absorbing Guardian metals? On the one hand it seems obvious that there must be provision for both: that what it is to acquire bronze in the soul during gestation just is to spend time learning a craft and practising with the relevant equipment. If we are to speculate, the best guess seems to be that the education starts out the same for all, and then as the metals become apparent, students must choose or be directed towards routes that suit their talents, though all are still in the same underground womb. When they are born fully grown with their manufactured equipment $(4 \mid 4 \mathrm{~d} 8)$ we need not suppose that this is just the arms and weapons for the ones entering the professional military (those had already been mentioned at line 7); it will also include the anvil, or the potter's wheel. The citizens must have tools for their profession, and an education that fits them for citizen life and their role within it.

At $456 \mathrm{~d}$ Socrates says some rather disparaging things about the craftsmen, describing their education as much inferior to that of the Guardians. ${ }^{62}$ "In the city which we have founded," he says, "which are the superior men, the Guardians (having had the education we've just described), or the shoemakers who've been educated in shoemaking?" "Silly question," says Glaucon. If this refers to two wholly separate training schemes, as many suppose, then it precludes social mobility (as Hourani noted), if the children are assigned to those schools before their metals are apparent, on the basis of

${ }^{61}$ Evidence for a period of apprenticeship at 467 a where Socrates remarks that potters' children spend years watching and learning at their father's side before making pots themselvesthough this may be about apprentices in Athens, not in the new republic. His point is that Guardian children in the new state should have an apprenticeship at least as long as the potters' children currently get. Also 456d (where Socrates is disparaging about the inferior education of the workers, on which see below).

${ }^{62}$ See above, note 61. 
some other criterion such as birth. ${ }^{63}$ Socrates makes this remark in relation to the schooling of Guardians: his point is that some women may also be suited for Guardian studies. He thereby implies that these girls, like the Guardian boys, get a classier education than the one given to those destined to be shoemakers. However, we should not infer that those cobbler boys, who get the inferior education, were picked out as Craftsman material, not Guardian material, before their metals started to become apparent; nor that those Guardian girls were already assigned to Guardian studies before their metals started to show. Neither could have been sent to their respective schooling on any basis other than the emergence of some relevant metals. And indeed, for the social mobility requirement, all we need is the proviso that any specialisation there may be, in the common schooling, must be congruent with the metal of the child's soul, and not determined by anything else.

So even if, by their teenage years, these different youths are pursuing rather different studies, yet it is most important (for unity and brotherhood) that they are not in a different womb, and they will not be born any sooner. They must all continue to be nurtured underground together, until both groups have a complete deposit of metals, whether these are developed through practical exercises or intellectual training, or both. All of them will be born when their respective metal deposits are complete and when all are ready to enter an adult life, whether it be a life of military service, intellectual endeavour or productive work.

\section{Is it important that the rulers believe it first? And is}

\section{it actually a lie?}

As we noted above (Section VI.i), Socrates says, at 4I4d2 (TI0), that he will try to persuade first the rulers themselves, and the military, and then the rest of the city. A little earlier, at $4 \mid 4 \mathrm{cl}$ (T9), he had said he will persuade especially the rulers, or, failing that, the rest of the city. Both passages imply that this might be difficult, but both imply that the top priority is to convince the rulers.

It seems natural to take both passages to be recommending the same ambition, for the same reason. The potential failure, expressed in one case by "or, failing that, ..." and in the other by "I will

\footnotetext{
${ }^{63}$ Hourani, 'Education', 59.
} 
try to persuade", is presumably the same. He considers that, as a second best, he might have to persuade the rest instead, if it fails with the rulers.

Does this mean that he doesn't care whether the rulers believe it, and he really only wants the rest to be duped? That seems to me to be far from what is meant. In both texts, Socrates puts the top priority on convincing the rulers that their education was underground. We should not take his fear of failure to indicate that failing would not matter. In fact, it seems that everything depends upon the rulers being unswervingly committed to this myth and completely immune to any temptation to question it. Their unquestioning adherence to its provisions is of great practical significance for the city.

In addition, it is hugely significant morally. It makes the difference between a regime that rules by deception and a society that values integrity. If the rulers do not believe the ideology, but impose it by telling lies to the other classes, then their rule lacks the legitimacy and security that comes from consensus and shared commitment to common ideals. The Noble Lie is much more noble, a morally superior proposal, if Socrates means that the rulers follow and recommend principles whose truth and worth they genuinely endorse.

These are among many reasons why the passage makes no sense unless Plato genuinely means that the rulers above all must be convinced, and that it is a matter of great importance that the rulers are not intentionally deceiving the people or concealing something that they know but others must not know, as though the class system were like the marriage numbers, delivering results that are untrue but convenient for some unmentionable purpose. ${ }^{64}$

Given how important this is, I do not think that it is at all desirable to settle the apparent discrepancy between the formulation at $4 \mid 4 \mathrm{cl}$ ("especially the rulers, or failing that...") and at $4 \mid 4 \mathrm{~d} 2$

${ }^{64}$ The marriage numbers are a case of genuine lying, because they conceal something that the rulers know but those affected must not know (for pharmacological reasons). The noble lie is not like that. It aims to see justice done, by placing people in appropriate roles: not something to be concealed. No one is trying secretly to put people in the wrong roles. So it resembles the healthy stories of gods and heroes, which are not intended to deceive but to convey the truth in palatable form. The truth in question is not unmentionable, on anyone's story except Popper's (which has no support in the text). 
("first the rulers... then after that the rest") by supposing that it always means "try but actually fail to convince the rulers", as though the rulers never need to believe it. Such an admission of defeat, before they have even considered how the persuasion might be achieved, would be gross and imperfect. But in any case, now that we have found good reasons both for why it is true in a certain sense-in that it tells (by means of a stylised story) the truth about how students differ in aptitude by the time they leave school-and why the rulers would actually be more than willing to believe it, including its subterranean imagery, as a result of their superior knowledge, there is no reason for Socrates to retain any doubts. Any doubts about how to convince them will have dropped away once the message of the Cave motif has been absorbed.

One reason why the worries drop away is because the metaphors in the myth of the metals turn out to be useful ways of expressing the truth about the things that the myth is supposed to govern. It could be said, then, that the reason why the lie ceases to be troublesome is because it is not really a lie, and that means that something has been lost in the solution. What happened was not that we found a way to deceive the rulers, but that we found that no deception was required and it was not a lie after all.

That would be one way to explain what has happened. If that is what has happened, should we then object to Plato's procedure, introducing it as a lie and then showing that for his society it is not a lie after all? There are clearly good dramatic reasons for that procedure, and also some political reasons, in that it subtly accuses societies that use such myths, to privilege certain families, of living by a lie, whether or not their rulers believe the lies they peddle. For them, the lie defends privilege by birth instead of eliminating it, and for them it is a lie.

Alternatively we might say that its falsity has not been removed. It remains literally false that the education was underground, that it was all a dream, that it instilled minerals such as gold and copper and so on. All these are metaphor. The earth is not our birth mother, and what was provided in the education was provided by the state, not the earth. Any truth in this myth is not in its mythical motifs, rich though they are as metaphors, but in what they stand for, as the rulers will realise.

So perhaps after all, the rulers will see through the myth to its truth, in a way that other citizens will not. It transpires then, that although the rulers do believe it, and do not deceive or lie to the people in teaching them the myth, it will never be more than a believable myth for the ordinary people, while it is only the philosophers who will know how true it is and why. So there is, after all, a 
difference in their epistemic relation to what they believe, and the kind of persuasion achieved. The rulers will believe and understand why, while the people will just believe (and that will be wisdom for them too). ${ }^{65 *}$

\section{Bibliography}

Adam, J., The Republic of Plato (ed. Plato; Cambridge, 1902).

Bloom, H. (ed.), Rebirth and Renewal (New York: Infobase Publishing, 2009).

Clay, D., 'Plato's First Words', in F. M. Dunn and T. Cole (eds.), Beginnings in Classical Literature (Yale Classical Studies; New York, 1992), I I3-29.

Hesk, J., Deception and Democracy in Classical Athens (Cambridge, 2000).

Hourani, G. F., 'The education of the third class in Plato's Republic' [Education], Classical Quarterly, 43 (1949), 58-60.

Irigaray, L., Speculum of the other woman, trans. G. C. Gill (Ithaca, 1985).

Krumnow, K. L., 'Womb as Synecdoche: Introduction to Irigaray's Deconstruction of Plato's Cave', Intertexts, I3 (2009), 69-93.

Loraux, N., Les Enfants d'Athéna (Textes a L'Appui; Paris, 198I).

Loraux, N., The invention of Athens: The Funeral Oration in the Classical City, trans. A. Sheridan (Cambridge Mass., 1986).

Loraux, N., The Children of Athena [Children], trans. C. Levine (Princeton, 1993).

Murray, P., 'What is mythos for Plato', in R. Buxton (ed.), From Myth to Reason (Oxford, 1999), 25I62.

Nightingale, A. W., Spectacles of Truth in Classical Greek Philosophy: Theoria in its cultural context (Cambridge, 2004).

Page, C., 'The truth about lies in Plato's Republic', Ancient Philosophy, II (199I), I-33.

Popper, K., The Open Society and its enemies Volume I: Plato (London, 1945).

Rosenstock, B., 'Athena's cloak: Plato's Critique of the Democratic City in the Republic', Political Theory, 22/3 (1994), 363-90.

Saxonhouse, A., 'Myths and the origins of Cities: reflections on the autochthony theme in Euripides' Ion', in P. J. Euben (ed.), Greek Tragedy and Political Theory (Berkeley, 1986), 252-73.

Schofield, M., Plato: Political Philosophy [Plato] (Founders of Modern Political and Social Thought, ed. M. Philp; Oxford, 2006).

Schofield, M., 'Metaspeleology', in D. Scott (ed.), Maieusis (Oxford, 2008), 2I6-3I.

${ }^{65}$ See Republic $428 b-429 a$ on how the society counts as wise.

* Earlier versions of this paper benefited from oral discussion in Cambridge, Uppsala, Dublin, and Edinburgh, and from written comments from Malcolm Schofield, David Robjant, Alan Finlayson, and two anonymous readers for another journal. The current version owes a lot to wonderfully constructive criticisms and suggestions from Victor Caston and two OSAP referees. I would also like to thank Carol Atack for alerting me to relevant works by Loraux and Irigaray. 
Ustinova, Y., Caves and the Ancient Greek Mind. Descending underground in the search for ultimate truth (Oxford, 2009).

Wardy, R., 'The Platonic Manufacture Of Ideology, Or How To Assemble Awkward Truth And Wholesome Falsehood' [Ideology], in V. Harte and M. Lane (eds.), Politeia in Greek and Roman Philosophy (Cambridge, 20I3), II9-I38. 